
78 巻 791 号 2012-7)

\title{
液滴衝撃エロージョンに及ぼす衝突角度の影響*
}

服部 修次 ${ }^{* 1}$, 角一 将也*2

\section{Effect of Impact Angle on Liquid Droplet Impingement Erosion}

\author{
Shuji HATTORI ${ }^{* 1}$ and Masaya KAKUICHI \\ ${ }^{* 1}$ Graduate School of Engineering, University of Fukui, \\ 3-9-1 Bunkyo, Fukui-shi, Fukui, 910-8507 Japan
}

In steam piping system containing liquid droplets, pipe wall is sometimes damaged by droplet impingement. One of the most important parameters affecting erosion is impact angle. No research has been conducted for the impact angle dependence on erosion for pipe steels. In this study, jet nozzle was used for the high pressure impingement tests of S15C, SUS304 and STPA24, and spray nozzle for the tests of pure aluminum. The MaxDER (Maximum Depth of Erosion Rate) for these three steels was expressed as $\sin ^{\mathrm{n}} \theta$ and the exponent is $1.2-2.5$ irrespective of type of steels. Jet nozzle tests with $90^{\circ}$ specimen showed that liquid droplet impingement was weakened possibly due to the liquid film formation. Spray nozzle tests revealed that the erosion can be estimated safely in terms of $V=V_{0} \sin \theta$.

Key Words: Liquid Droplet, Erosion, Impact Angle, Jet Nozzle, Spray Nozzle

\section{1. 緒言}

液滴衝撃エロージョンは, 発電プラントの配管で問題になっている減肉現象の一つで，液体の漏洩に繋がる重要な問 題である(1). 液滴衝撃エロージョンの主だった発生箇所としては，エルボ下流部の外側・T字管などの流れの方向が変 化する部分，オリフィスや弁直後の配管，ドレイン系配管などの凝縮水と蒸気が混在する箇所などが挙げられる. 液滴 衝撃エロージョンは破損の状況から見ると, 口径の小さい貫通孔による蒸気または凝縮水のリークなどの軽微な損傷で 留まっており，大惨事につながる可能性は少ないとしても，発電所を安定的・継続的に運転させる観点から，液滴衝撃 エロージョンを詳細に評価することは大変重要である.

液滴衝撃エロージョンに関する初期の研究は, 雨中を航行する航空機の空材料や低土蒸気タービンのブレード等を対 象に行われた ${ }^{2}$. 液滴衝撃エロージョンに影響する因子としては, 流速, 液滴径, 衝突角度などが挙げられる. 液滴径 の影響については, その結果を報告(3)している. 液滴衝撃エロージョンに及ぼす衝突角度の影響に関する研究では, Fyall ら (4) がアクリル樹脂を用いてエロージョン試験を行い，エロージョンの発生では流速の垂直成分が重要であると報告 している. Busch ら ${ }^{(5)}$ は，6 種類のプラスチックやセラミックスを用いてエロージョン試験を行い，試験面の法線方 向と液滴の入射方向のなす角を $\alpha$ とすると, エロージョン発生に対する限界流速は $V_{0} / \cos \alpha$ にり表示できることを 報告している. Hoff ら ${ }^{(6)}$ は，液滴衝撃エロージョンに関する種々の研究を調査し，流速の垂直成分のみが液滴衝撃エ ロージョンに影響するとしている. Baker ら ${ }^{(7)}$ は， $12 \mathrm{Cr}$ 鋼を用いてエロージョン試験を行い，質量減少速度が( $V \sin$ $\theta-V \mathrm{c})^{\mathrm{n}} / \sin \theta(V \mathrm{c}$ : 限界流速， $\theta$ : 試験面と液滴の入射方向のなす角）に依存することを報告している. また，Hoff らは，平均壊食深さ速度 $\mathrm{MDPR}$ が $(V \sin \theta-V \mathrm{c})^{\mathrm{n}} / \sin ^{2} \theta$ で表示できることを報告 (8) し，その後 Hammitt ら (8) は, ロケット滑走試験によるバイオセラムプラスチックのデータを用いて, $\mathrm{MDPR}=K(V \sin \theta-V \mathrm{c})^{\mathrm{n}} / \sin ^{\mathrm{x}} \theta$ とおいて $\mathrm{n}$ と $\mathrm{x}$ の統計解析をし $\mathrm{x}$ を 1 から 2.5 まで変化させても誤差はそれほど変化しないので簡単のために $\mathrm{x}=1$ とするのが適 切であると報告している. Schmitt ら (9) は, プラスチック, セラミックス, ガラス, 金属, 複合材料の合計 21 種類の

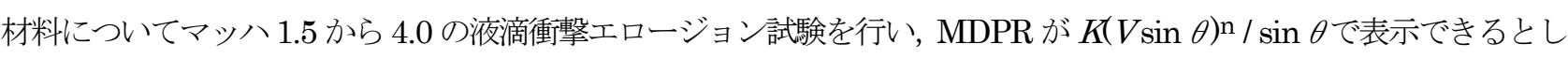

\footnotetext{
* 原稿受付 2012 年 1 月 13 日

*1 正員, フェロー, 福井大学大学院工学研究科 （广910-8507 福井県福井市文京 3-9-1）

*2 福井大学大学院工学研究科

E-mail: hattori@u-fukui.ac.jp
} 
て，各種材料について $\mathrm{n}$ と $K$ の值を得ている. また Schmitt ら ${ }^{(10)}$ は， 3 種類のセラミックスと 8 種類のプラスチッ ク複合材料を用いて $1700 \mathrm{~m} / \mathrm{s}$ でエロージョン試験を行い, MDPR がマッハ 5 以上では $K{ }^{n} \sin ^{2} \theta$ で表示できるとして 各種材料の $\mathrm{n}$ と $K$ の值を得ている. 一方, Gorham ら ${ }^{(11)}$ は, 積層複合材料の剥離損傷では衝突角度の関係は単純で はなく流速に依存して $\theta$ が $60^{\circ}$ から $80^{\circ}$ でピークが現れるとしている. また最近, Ahmad ${ }^{(12)}$ らは, 4 種類のステン レス鋼と 1 種類のチタン合金を用いてエロージョン試験を行ってエロージョンの材料依存性を詳細に検討しているが, 衝突角度依存性については $13 \mathrm{Cr}$ 鋼の从を用いて試験を行っているだけで, 衝突角度 $90^{\circ}$ でエロージョン速度が最大と なる従来と同様の傾向を与えているのみである.

このように, 液滴衝撃エロージョンの衝突角度依存性の研究は, 航空機の空材料や低圧タービン翼の損傷が主な研究 対象となっていたために, ガラス, セラミックス, 強化プラスチック, $13 \mathrm{Cr}$ 鋼等の研究が主で, 配管材料の炭素鋼や オーステナイト系ステンレス鋼の研究はほとんど行われていない. また, 損傷量としては, 質量減少速度やMDPR（平 均壞食速度）で評価しており，配管減肉で問題となる最大深さの変化を取扱っている研究は報告されていない.

本研究では，ジェットノズルを用いて S15C，SUS304，STPA24 の液滴衝撃エロージョンに及ぼす衝突角度の影響 に関する材料依存性を検討するとともに, スプレーノズルを用いて純アルミニウムの衝突角度の影響について検討した。

\section{$2 \cdot 1$ 実験装置}

\section{2. 試験方法及び供試材料}

液滴衝撃エロージョン試験装置には，ASTM G134-95 ${ }^{(13)}$ に基づくキャビテーション噴流試験装置を使用した. ノズ ルは図 1 に示寸ジェットノズル（スギノマシン製Water Nozzle Size $\phi 0.40 \mathrm{~mm}$ ）とスプレーノズル（いけうち製高圧均 等肩形ノズル 1/8MVNP2525S303）を用いた. 図 2 に試験水槽の概略図を示寸. 試験液には水道水を用い, 水温が $25 \pm$ $2^{\circ} \mathrm{C}$ とるように制御した．水流の噴出直後の流速 $V$ は，ノズル入り口の圧力（上流圧）及び，ノズル出口の圧力（大

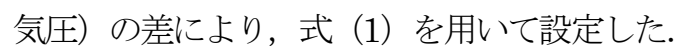

$$
V=\sqrt{\frac{2\left(p_{u}-p_{d}\right)}{\rho}}
$$

ここで， $p_{u}$ は上流圧， $p_{d}$ は水槽中の静圧（大気圧 $0.1 \mathrm{MPa}$ ）で， $\rho$ は水の密度である. 上流圧は $10.0 \sim 16.3 \mathrm{MPa}$ の 範囲で変化させた. また，純アルミニウム $\mathrm{Al}$ を用いて子備試験を行い，スタンドオフ距離（ノズル出口から試験面ま

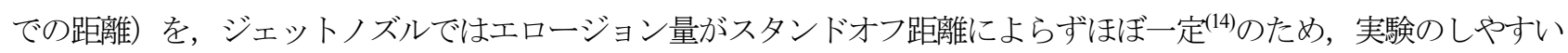
$15 \mathrm{~mm}$, スプレーノズルでは最もエロージョンが発生する $30 \mathrm{~mm}$ に設定した.

ジェットノズル試験では，試験片材料に S15C，SUS304，STPA24 を用い，上流圧を $16.3 \mathrm{MPa}$ に設定して流速 $180 \mathrm{~m} / \mathrm{s}$ で実験を行った. 所定の試験時間毎に試験片の質量, 表面形状を測定し, 試験時間に対し最大エロージョン深さ (MaxDE) をプロット，これより単位時間当りの最大エロージョン深さ速度（MaxDER）を求めた. スプレーノズル試験では, エ ロージョンの発生しやすい $\mathrm{Al}$ を用いて,上流圧を $10 \mathrm{MPa}$ (流速 $140 \mathrm{~m} / \mathrm{s}$ ) に設定して衝突角度の影響について検討した.
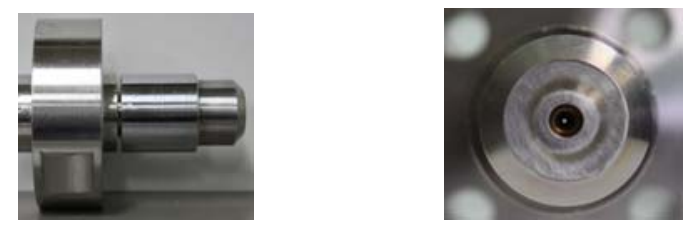

(a) Jet nozzle
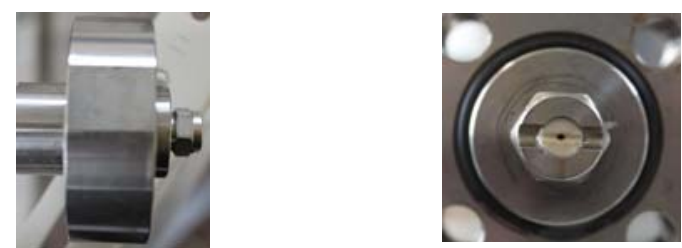

(b) Spray nozzle

Fig.1 Jet nozzle and spray nozzle

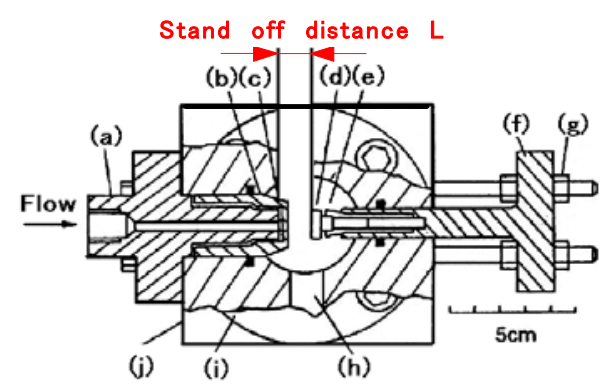
(a) Nozzle holder
(b) Nozzle holder nut
(c) Nozzle
(d) Specimen
(e) Specimen supporter
(f) Specimen holder

(g) Level control nut

(h) Flow ventage

(i) Window flange

(j) Body

Fig.2 Test chamber schematic view of high pressure method 


\section{$2 \cdot 2$ 供試材料}

本試験に用いた試験材料は，炭素鋼配管 STPG370 相当材料の S15C，ステンレス鋼配管相当材料の SUS304，配管用 合金鋼の STPA24 及び純アルミニウムAl であり，表 1 に化学成分を示す. S15C は，電気マッフル炉（ADVANTEC 製 FUL220FA）を用いて，910ㄷ゙ 10 分間保持後空冷の熱処理を施した. SUS304 及びSTPA24 は受け入れのままであり， 熱処理は行っていない. 表 2 に試験材料の物理的性質及び機械的性質を示す. 試験片は, 図 3 に示すディスク直径 $12 \mathrm{~mm}$ の形状のものを，試験面が $90^{\circ} ， 60^{\circ} ， 45^{\circ} ， 30^{\circ}$ になるように加工し，表面研磨して鏡面状にしたものを用いた. 実験結果は，所定時間毎に試験片をアセトン中で超音波洗浄した後，精密天秤（感度 $0.01 \mathrm{mg}$ ）で質量を測定し，非接 触表面形状測定システム（KEYENCE 製 LT-8010，分解能 $0.1 \mu \mathrm{m}$ ，測定間隔 $4 \mu \mathrm{m}$ ，最大測定深さ $500 \mu \mathrm{m}$ ）により試 験片の表面形状を計測して整理した.

\section{3. 試験結果及び考察}

\section{$3 \cdot 1$ ジェットノズルを用いたエロージョン試験結果}

図 4 は流速 $160 \mathrm{~m} / \mathrm{s}$ におけるスギノマシン製ジェットノズル（ $\phi 0.4 ）$ からの液体の挙動を，高速度ビデオ (Photron 製

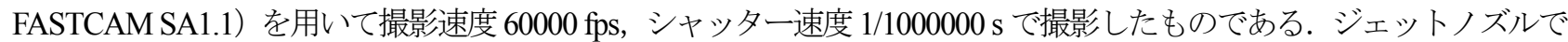
は，ノズル先端から噴出される液体は円柱状にならず，球状の液滴が数珠繋ぎ状に噴出されているのが観察される. ジ エットノズルからの液滴径は，ノズル径にほぼ等しい約 $0.4 \mathrm{~mm}$ である.

Table1 Chemical composition of test materials

\begin{tabular}{|c|c|c|c|c|c|c|c|c|c|c|c|c|c|}
\hline Material & $\mathrm{C}$ & $\mathrm{Si}$ & $\mathrm{Mn}$ & $\mathrm{V}$ & $\mathrm{P}$ & $\mathrm{S}$ & $\mathrm{Cu}$ & $\mathrm{Ni}$ & $\mathrm{Mo}$ & $\mathrm{Cr}$ & $\mathrm{Al}$ & $\mathrm{Fe}$ & $\mathrm{Ti}$ \\
\hline S15C & 0.16 & 0.21 & 0.45 & - & 0.01 & 0.016 & 0.01 & 0.02 & - & 0.05 & - & $\mathrm{Bal}$ & - \\
\hline SUS304 & 0.06 & 0.2 & 1.67 & - & 0.034 & 0.027 & - & 8.0 & - & 18.73 & - & $\mathrm{Bal}$ & - \\
\hline STPA24 & 0.12 & 0.35 & 0.47 & 0.002 & 0.012 & 0.004 & 0.02 & 0.02 & 0.93 & 2.12 & 0.002 & $\mathrm{Bal}$ & 0.001 \\
\hline $\mathrm{Al}$ & - & 0.06 & - & 0.01 & - & - & 0.01 & - & - & - & $\mathrm{Bal}$ & 0.12 & 0.01 \\
\hline
\end{tabular}

Table 2 Mechanical properties of test materials

\begin{tabular}{|c|c|c|c|}
\hline Material & $\begin{array}{c}\text { Density } \\
\mathrm{kg} / \mathrm{m}^{3}\end{array}$ & $\begin{array}{c}\text { Tensile } \\
\text { strength } \\
\mathrm{MPa}\end{array}$ & $\begin{array}{c}\text { Vickers } \\
\text { hardness } \\
\text { HV0.2 }\end{array}$ \\
\hline S15C & $7.81 \times 10^{3}$ & 441 & 145 \\
\hline SUS304 & $7.93 \times 10^{3}$ & 694 & 171 \\
\hline STPA24 & $7.72 \times 10^{3}$ & 630 & 216 \\
\hline Al & $2.71 \times 10^{3}$ & 95 & 38 \\
\hline
\end{tabular}

(a) $90^{\circ}$

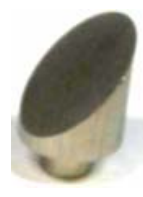

(c) $45^{\circ}$

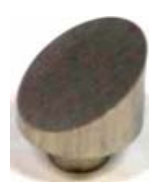

(b) $60^{\circ}$

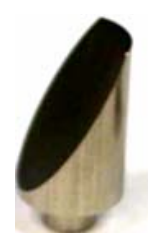

(d) $30^{\circ}$

$5 \mathrm{~mm}$

Fig.3 Test specimen

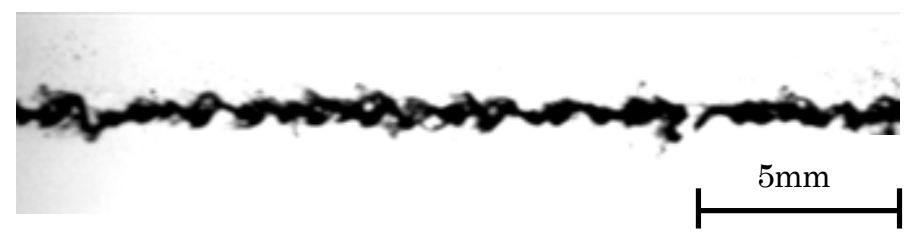

Fig.4 High speed camera photograph (Flow velocity $160 \mathrm{~m} / \mathrm{s}$ ) 
図 5 は $\mathrm{S} 15 \mathrm{C}$ の衝突角度 $90^{\circ} ， 60^{\circ} ， 45^{\circ} ， 30^{\circ}$ の質量減少量曲線である. 図 6 は, 図 5 に示寸質量減少量を試験材

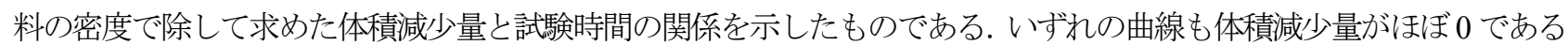
潜伏期を経て，減少量が急増後直線的に増加する最大速度期に至る. 潜伏期は液滴衝撃の繰り返し作用によって材料が 塑性変形しているが、材料の脱落は生じていない段階である。特に衝突角度 $90^{\circ}$ の場合，体積减少量は 1 時間の潜伏 期の後，最大速度期となり，3 時間後に約 $0.1 \mathrm{~mm}^{3}$ に達寸る. 衝突角度 $60^{\circ} ， 45^{\circ}$ の場合も，衝突角度 $90^{\circ}$ の場合と同 様に，体積减少量は潜伏期を経た後，短時間で急激に増加する．衝突角度 $30^{\circ}$ の場合，体積減少量は 4 時間の潜伏期 の後, 最大速度期となり, 15 時間後に約 $0.1 \mathrm{~mm}^{3}$ に達する. 衝突角度 $30^{\circ}$ では, 他の衝突角度の場合より単位時間当た りの体積减少量が小さく, 衝突角度 $90^{\circ}$ と同等の体積减少量に至るまでに約 5 倍の時間を要する. SUS304 及びSTPA24 の結果については紙面の都合上省略する.

S15C，SUS304，STPA24の体積减少量曲線から，各衝突角度の最大速度期における体積减少速度をそれぞれ読み取 り，衝突角度と体積减少速度の関係で表したものが図 7 である. それぞれの材料において，衝突角度と体積减少速度の 関係は $\sin ^{\mathrm{n}} \theta$ ( $\theta$ : 衝突角度) で表され，指数 $\mathrm{n}$ は S15C，SUS304，STPA24に対してそれぞれ 2.7，3.0，1.6 となり， ほぼ同程度の值をとる，どの材料においても，衝突角度が小さいとき体積减少速度は小さく，衝突角度が $90^{\circ} に$ に近づ くにつれて体積减少速度は急激に増加し，衝突角度 $90^{\circ}$ で体積减少速度は最大となる.

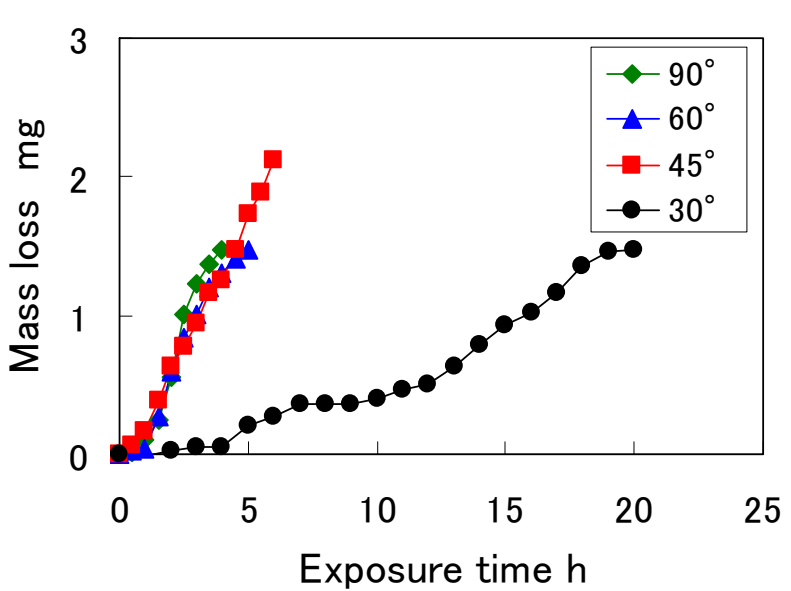

Fig.5 Mass loss-time curves of S15C (Jet nozzle, 180m/s)

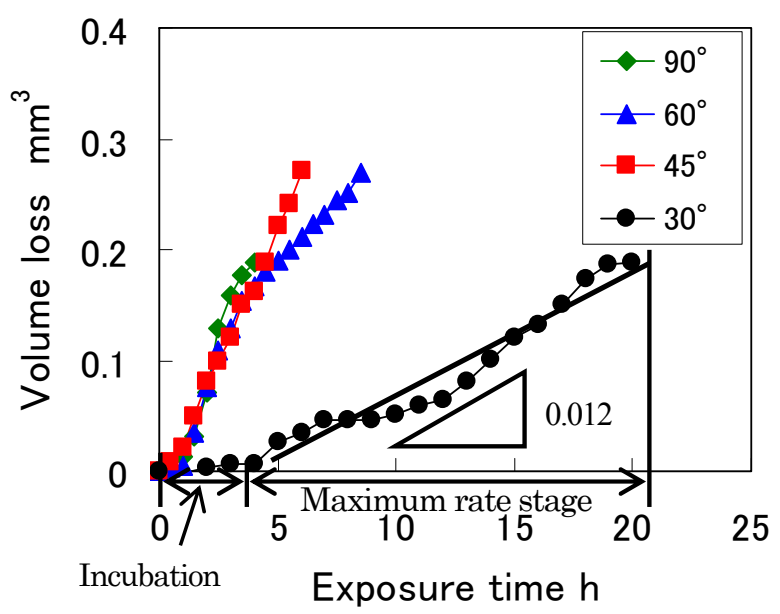

Fig.6 Volume loss-time curves of S15C (Jet nozzle, 180m/s)

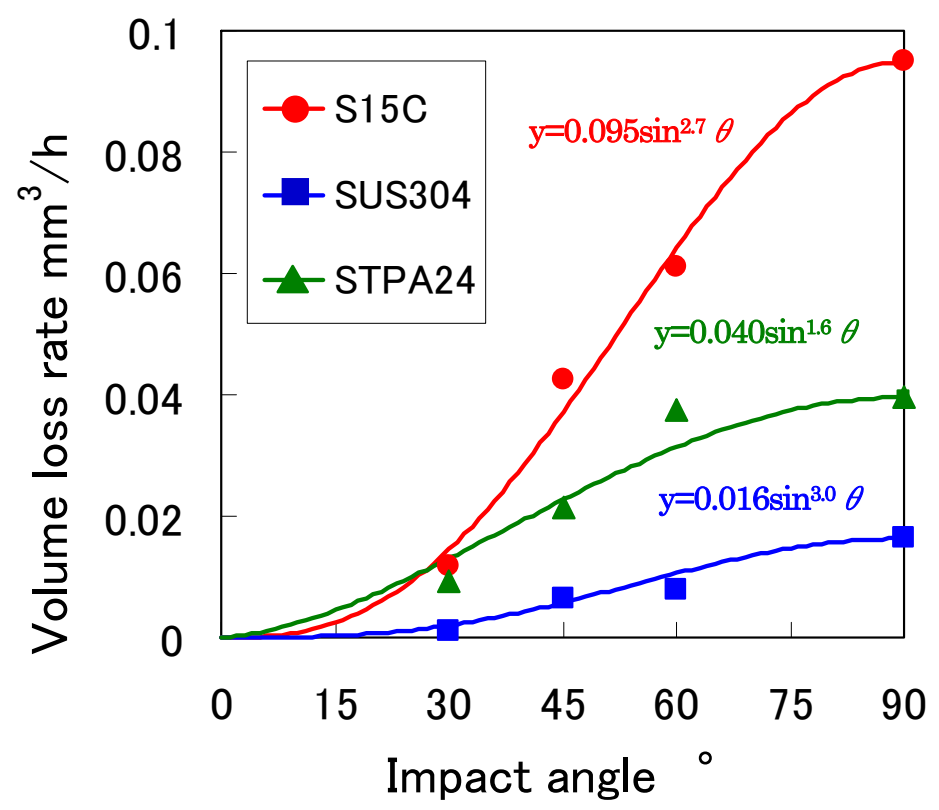

Fig.7 Relation between impact angle and volume loss rate (Jet nozzle, 180m/s) 
質量減少量は試験片全体からの脱落量を測定しているので, エロージョンによる質量減少量以外に試験片全体の腐食 の影響も含まれている恐れがある. また配管減肉では, 減肉の平均值よりも減肉の最大深さが重要となるので, 液滴衝 突部の最大深さで評価する方がより適切であると考えられる.

試験後の試験片のエロージョン深さを，表面形状測定器で測定した例を図 8 に示す. 赤色の部分が試験面の基淮面で あり，青色が濃くなるほどエロージョンによる損傷深さが大きいことを表している．青色部の最大深さを MaxDE と定 義した。

図 9 はS15C の衝突角度 $90^{\circ} ， 60^{\circ} ， 45^{\circ} ， 30^{\circ}$ の MaxDE 曲線である. 衝突角度 $90^{\circ}$ の場合, MaxDE は 1 時間の 潜伏期を経過後に最大速度期となり急激に増加し，2 時間後 MaxDE は約 $180 \mu \mathrm{m}$ に達する. 衝突角度 $60^{\circ} ， 45^{\circ}$ の場 合も, 衝突角度 $90^{\circ}$ の場合と同様に, MaxDE は短時間で急激に増加する. 衝突角度 $30^{\circ}$ の場合, MaxDE は 5 時間の 潜伏期の後, 最大速度期となりゆるやかに増加し， 15 時間後 MaxDE は約 $200 \mu \mathrm{m}$ に達する. 衝突角度 $30^{\circ}$ では, 他の 衝突角度の場合より単位時間当たりの MaxDE の変化量が小さく, 衝突角度 $90^{\circ}$ と同等の MaxDE に至るまでに約 5 倍 の時間を要する.

図 10 はSUS304 の MaxDE 曲線である。 S15C の場合と同様に, 衝突角度 $90^{\circ} ， 60^{\circ} ， 45^{\circ}$ では MaxDE は潜伏期を 経た後急激に増加するが, 衝突角度 $30^{\circ}$ ではゆるやかに増加する. すべての衝突角度において S15C の場合より MaxDE が 小さい. また S15C が時間の経過とともに MaxDE が増加するのに対し，SUS304 では時間の経過とともに MaxDE の変化は小さくなり，上に凸の曲線となっている．これは，SUS304の加工硬化性が大きいためであると考えられる.

図 11 はSTPA24 の MaxDE 曲線である. STPA24 の場合も，S15C の場合と同様に，明瞭な潜伏期及び最大速度期が 現れ，時間の経過とともにMaxDE は増加する.また，S15Cに比べて潜伏期の長さに及ぼす衝突角度の影響が明膫に現 れている.

\begin{tabular}{|c|c|}
\hline Material & $\mathrm{S} 15 \mathrm{C}$ \\
\hline $\begin{array}{c}\text { Impact } \\
\text { angle }\end{array}$ & $90^{\circ}$ \\
\hline $\begin{array}{c}\text { Upstream } \\
\text { pressure } \\
(\mathrm{MPa})\end{array}$ & 16.3 \\
\hline $\begin{array}{c}\text { Flow velocity } \\
(\mathrm{m} / \mathrm{s})\end{array}$ & 180 \\
\hline Time $(\mathrm{h})$ & 2.5 \\
\hline
\end{tabular}

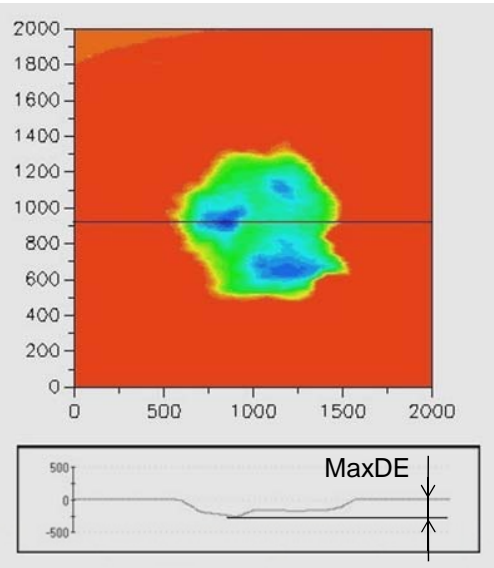

Fig.8 Definition of MaxDE

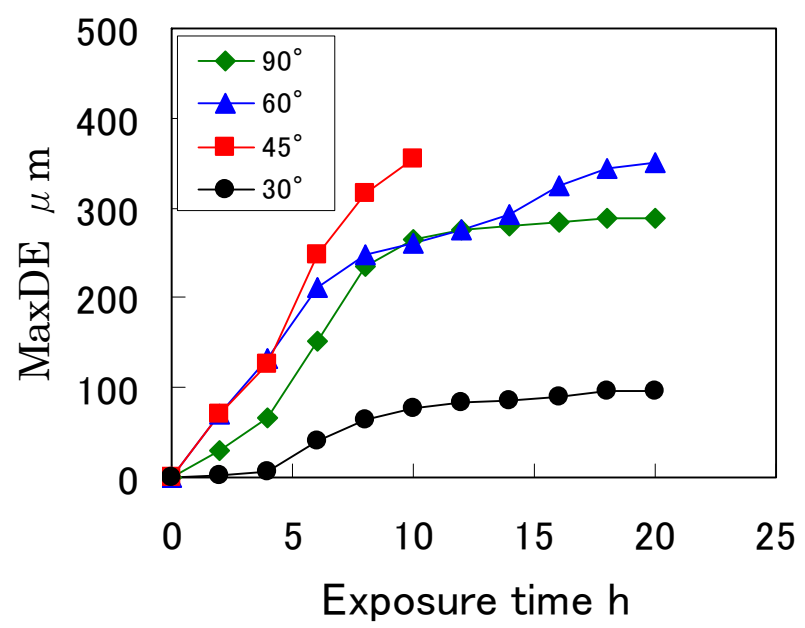

Fig.10 MaxDE-time curves of SUS304 (Jet nozzle, 180m/s)

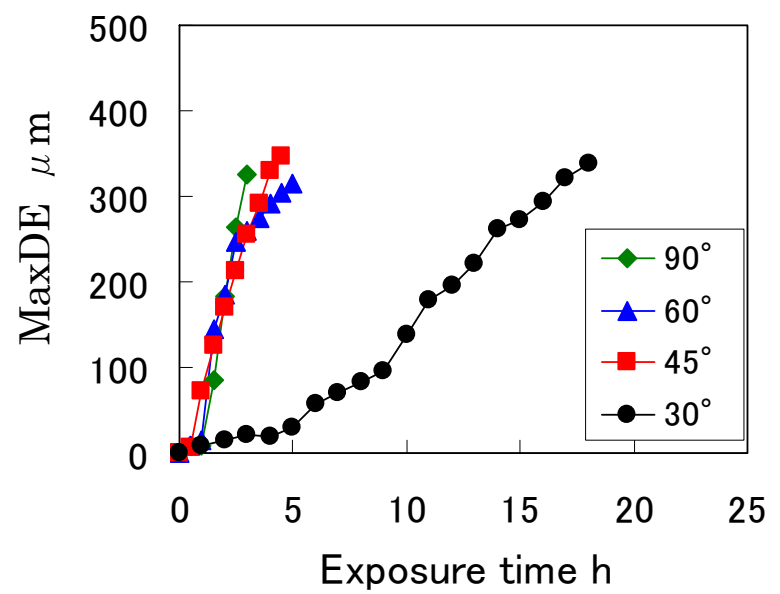

Fig.9 MaxDE-time curves of S15C (Jet nozzle, 180m/s)

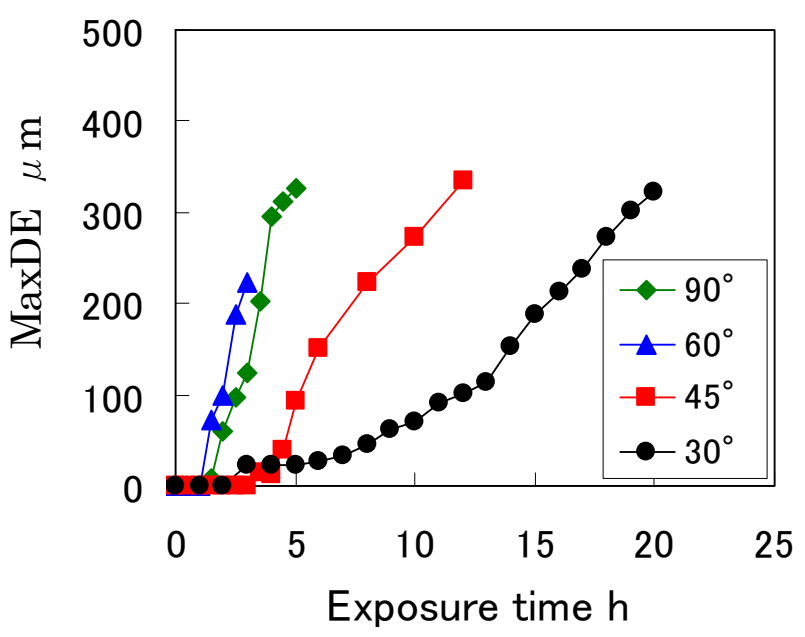

Fig.11 MaxDE-time curves of STPA24 (Jet nozzle, 180m/s) 
各材料の MaxDE 曲線から, 各衝突角度の最大速度期における最大エロージョン速度 MaxDER（MaxDE の変化速度）

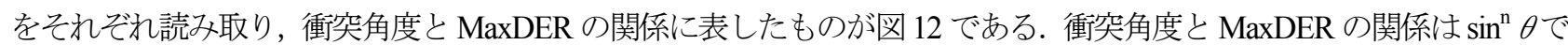
表され，どの材料においても，衝突角度が小さいほど MaxDER は小さくなり，衝突角度が $90^{\circ}$ に近づくにつれて MaxDER は急激に増加し，衝突角度 $90^{\circ}$ で MaxDER は最大となる。指数 $\mathrm{n}$ はS15C が 1.7, SUS304 が 1.2, STPA24 が 2.5 となり，ほぼ同程度の值をとる．また，指数 $\mathrm{n}$ は体積减少速度一衝突角度関係図（図 7）の場合の $1.6 \sim 3.0$ とほぼ同 程度の值をとっている.

図 13 はS15C の衝突角度実験での流速の垂直成分 $V \sin \theta$ に対する MaxDER（青色線）と，衝突角度 $90^{\circ}$ の試験片を 用いて流速を変化させて求めた流速に対する MaxDER (赤色線)を比較したものである.流速を変化させた時の MaxDER

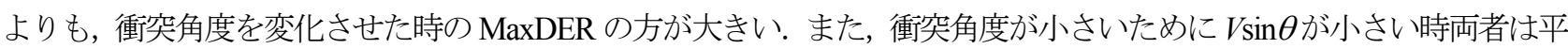
行な值をとり, 衝突角度が大きくなって $V \sin \theta$ が大きくなるにつれて MaxDER は同程度の值をとる．SUS304, STPA24 においても S15C の場合と同様の傾向を示寸が，紙面の都合上省略する.

以上の結果から, 試験面に衝突した液滴が, 試験面上で水膜を生成し, エロージョンの進行を妨げていると考えられ, 図 14 （a）に示寸ように，衝突角度が小さいとき，試験片表面の液膜は吹き飛ばされて水膜の保護作用がほとんどな い状態でエロージョンが発生すると考えられる，一方衝突角度 $90^{\circ}$ では，図 14 (b) に示寸ように，試験片表面に厚 い液膜が生じ，水膜の保護作用の下でエロージョンが進むので，低角度の試験結果から予測される MaxDER よりも小 さくなったものと考えられる。

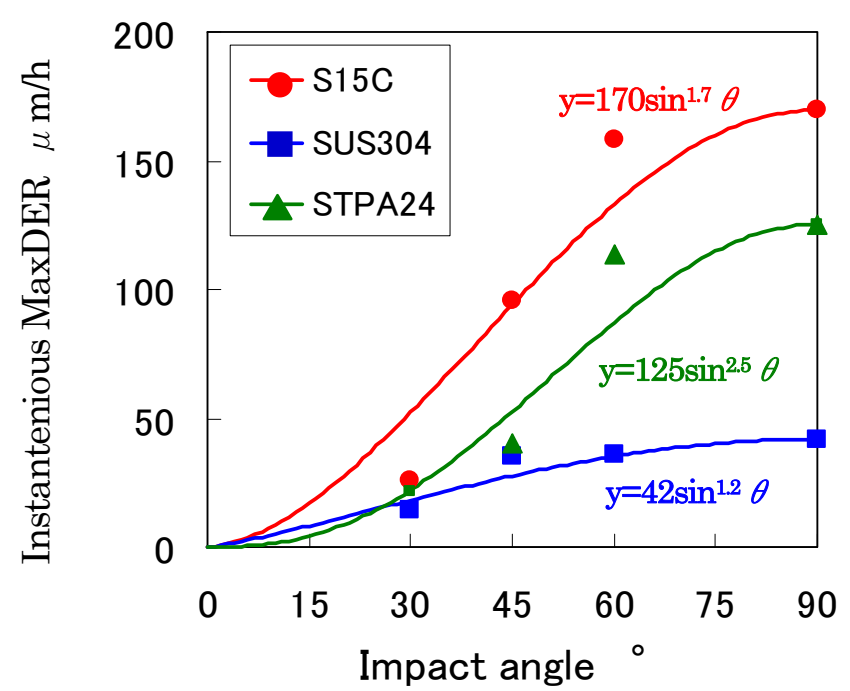

Fig.12 Relation between impact angle and MaxDER （Jet nozzle, $180 \mathrm{~m} / \mathrm{s} ）$

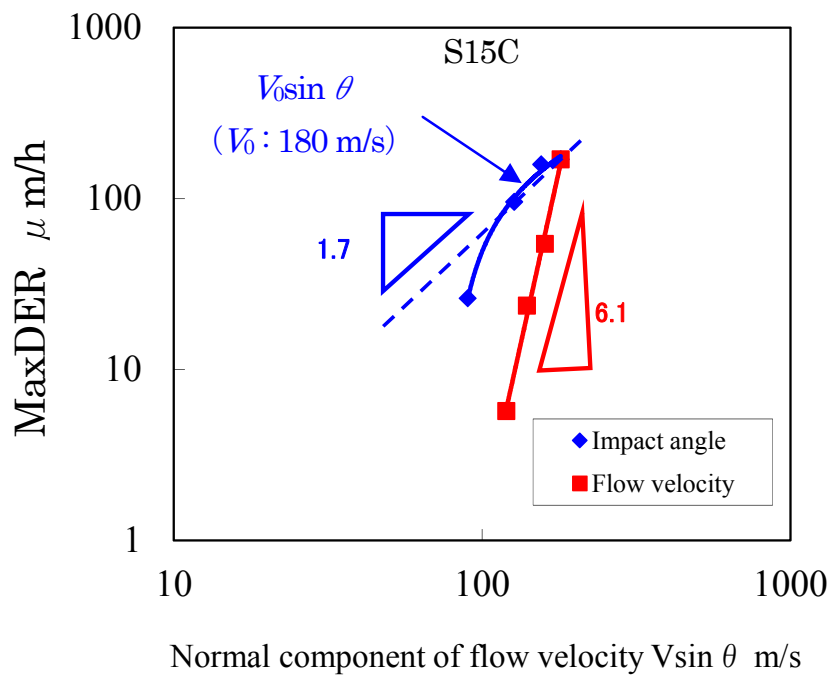

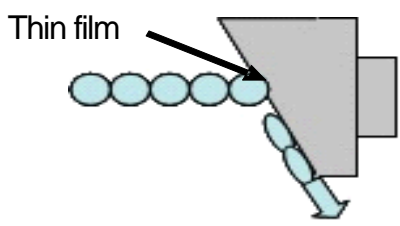

(a) Low impact angle

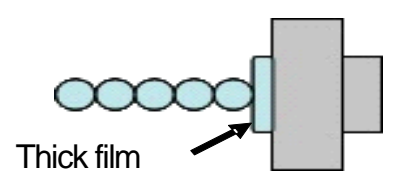

(b) Impact angle $90^{\circ}$

Fig.14 Effect of liquid film

Tig.14 Efect of 1 inid

Fig.13 Relation between normal component of flow velocity $V \sin \theta$ and MaxDER 


\section{$3 \cdot 2$ スプレーノズルを用いたエロージョン試験結果}

前節では，ジェットノズル（スギノマシン製Water Nozzle size $\phi 0.40 \mathrm{~mm}$ ）を用いたエロージョン試験では $90^{\circ}$ の衝 突角度で試験片中心部に液膜が生じてエロージョンが弱められることが考えられたので, 本節では扇形スプレーノズル

（いけうち製高圧均等扇形ノズル 1/8MVNP2525S303）を使用してエロージョン試験を行った．スプレーノズルを使用 すると液滴径が非常に小さいために，S15C の試験片ではエロージョンが進行しにくいと考えられたので，純アルミニ ウムの試験片を用いてエロージョン試験を行った.

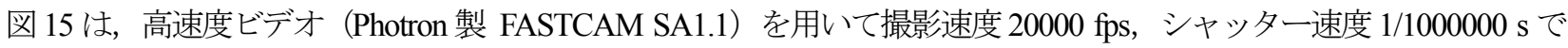
スプレーノズルからの液体の挙動を上方から撮影したものである. 図の赤線に示寸ように, スプレーノズルの先端から 高密度の液滴の領域が角度 $25^{\circ}$ で扇形に噴出されているのがわかる.

図 16 はスプレーノズルからの液体の挙動を撮影速度 $60000 \mathrm{fps}$ で側面から撮影したものである. 液滴径のザウター平 均值は，同一ノズルを使用している新潟大学の藤沢研究室のデータを参考にすると， $110 \mathrm{~m} / \mathrm{s}$ のさ $66 \mu \mathrm{m}$ である.

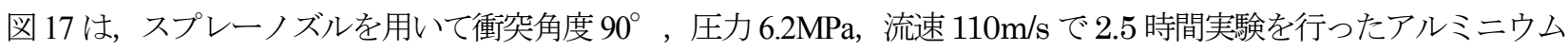
試験片の状態である. 試験片のエロージョン範囲は試験片中央部に直線状に発生し, 幅約 $3 \mathrm{~mm}$, 深さ約 $2 \mathrm{~mm}$ である. 前節のように, エロージョンによる最大深さを計測しようとしたが，非接触表面形状測定システムの最大測定可能深さ 以上に深くエロージョンが進行すること, 点レーザであるためにエロージョン領域全体を測定するのにかなり長時間を 要すること, 試験片が純アルミニウムのためにエロージョン領域以外は減肉していないことから, 実験結果は質量減少 量で整理した.

図 18 は衝突角度 $90^{\circ}$ の $\mathrm{Al}$ 試験片の質量減少量曲線である. 流速が速くなるにつれて, エロージョンによる質量減

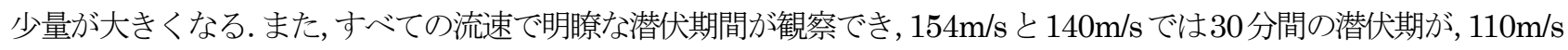
では 3 時間の潜伏期が現れる. それぞれの流速で潜伏期が終了した後, 質量減少量が著しく増加する最大速度期が観察 できる.

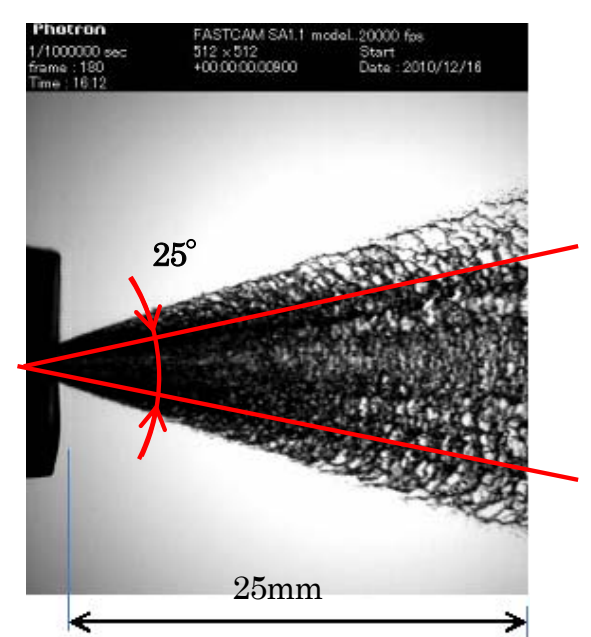

Fig.15 Top view of spray nozzle

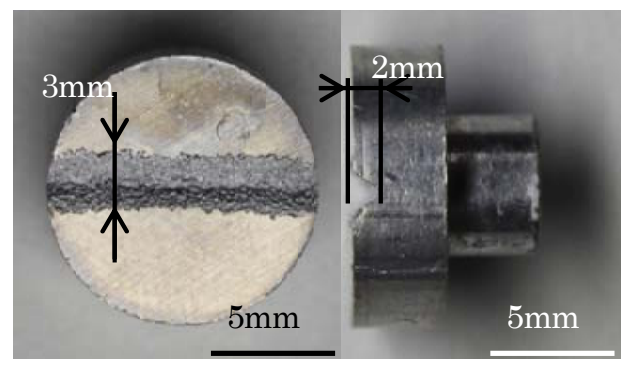

Fig.17 Test specimen after 2.5hour, 6.2MPa

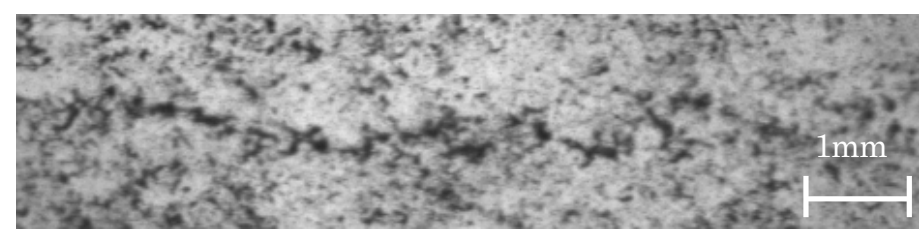

Fig.16 High speed camera of spray nozzle $(110 \mathrm{~m} / \mathrm{s})$

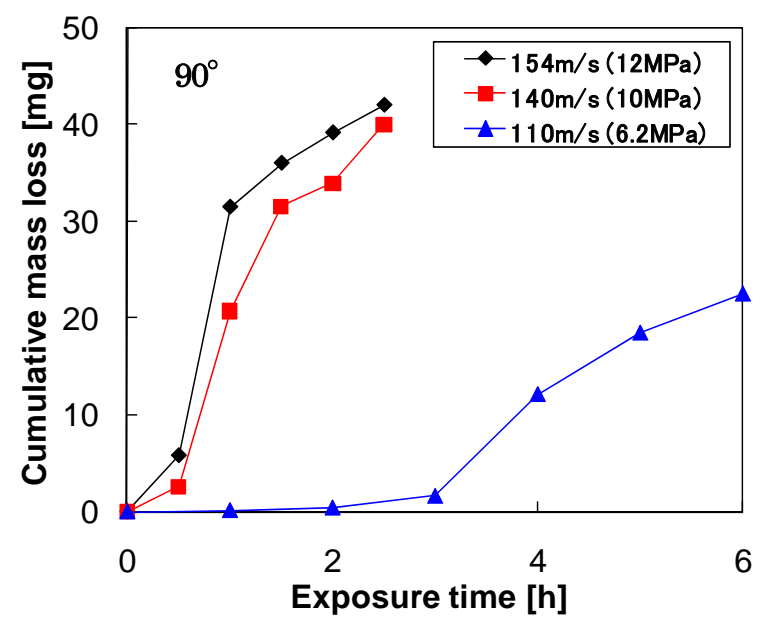

Fig.18 Mass loss-time curves of aluminum (Spray nozzle, 90 $\quad$ ) 
図 19 は衝突角度 $60^{\circ}$ ，流速 $140 \mathrm{~m} / \mathrm{s}$ で試験したときのアルミニウム試験片の質量減少量曲線である。（1）の試験は, 試験面を上向きにしてエロージョン試験を行った結果であり, 質量減少量は 3 時間まではゆるやかに増加し，これ以後 比較的急勾配に増加して 5 時間後に $10 \mathrm{mg}$ に達する. 一方，（2）の試験は試験面を下向きにしてエロージョン試験を行 った結果であり, 質量減少量は短い潜伏期の後, 最大速度期で急激に増加し, 2 時間後には $22 \mathrm{mg}$ に達寸る. このよう に試験片下向きの方が試験面上向きより質量減少量が約 9 倍大きいことが観察された. 試験面上向きと試験面下向きで 質量減少量が大きく異なるのは, 試験面下向きの試験片では, 試験面に衝突した液滴は液膜を作りにくいのに対して, 試験面上向きの試験片では, 液滴が試験面に衝突後飛散するときに, 重力により試験面上に液膜を作りやすく, 液膜の クッション効果によりエロージョン速度が低下したためと考えられる．実験の再現性を検討するため，（1）及び（2） と同条件で試験面上向き（3）及び試験面下向き（4）の実験を行った．（3）の試験は，(1）の結果とほぼ同様のエロー ジョン傾向を示した．（4）の試験は，（2）よりも潜伏期間が長いが，同様のエロージョン傾向を示した.

図 20 は衝突角度 $45^{\circ}$ のアルミニウム試験片における様々な流速での質量減少量曲線である. 衝突角度 $60^{\circ}$ の試験 片の場合とは全く反対の結果となり, 衝突角度 $45^{\circ}$ の試験片は下向きではほとんどエロージョンが発生しないが, 上 向きでは質量減少量が著しく増加する。これは試験槽の構造上，衝突角度 $45^{\circ}$ の試験面上に衝突した液滴が真上に飛 散し，真上にある観察空に垂直に衝突し，衝突した液滴が飛散して試験槽中で霧状になるために，ノズルから噴出され る液滴がこの霧状の液滴と合体して大きな液滴となり, 著しい損傷を与えたものと考えられる。このように, 衝突角度 $45^{\circ}$ 試験面上向きの場合は非常に特殊な状態であったと考えられるため, 試験面下向きの場合のみを検討した.

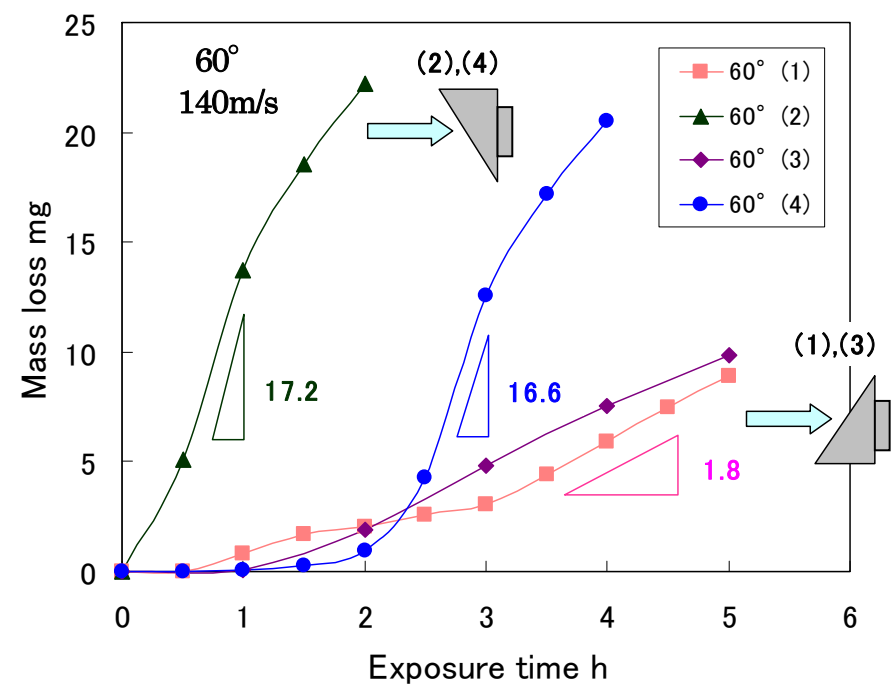

Fig.19 Mass loss-time curves of Al (Spray nozzle, 60 $\quad$ )

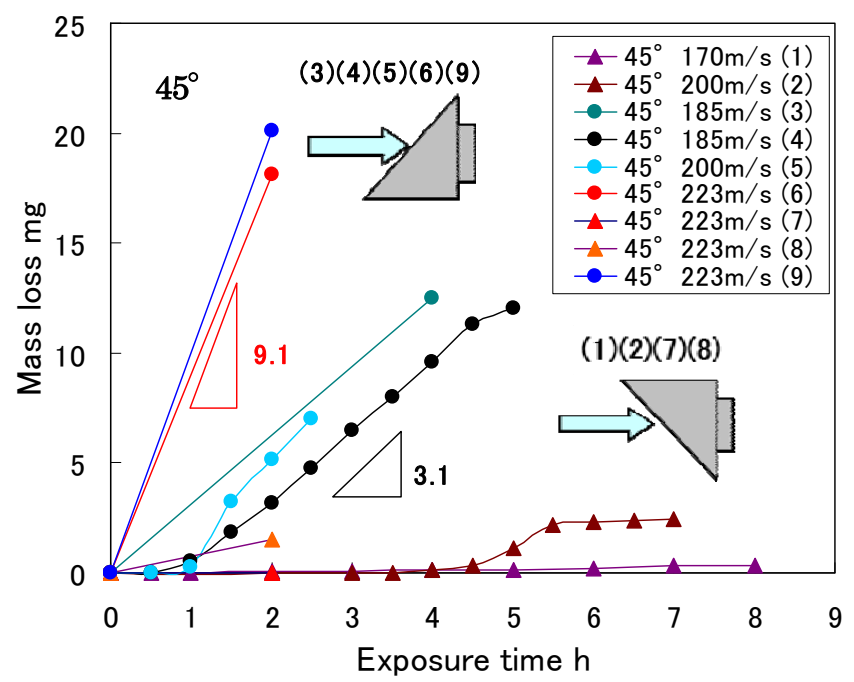

Fig.20 Mass loss-time curves of Al (Spray nozzle, 45 $\quad$ ) 
図 21 は衝突角度 $60^{\circ}$ のアルミニウム試験片を用いて，試験面を下向きにして実験を行った各流速の質量減少量曲線 である. 衝突角度 $90^{\circ}$ の場合と同様に，質量減少量は潜伏期間を経た後，最大速度期で著しく増加する．また，流速 が速くなるにつれて質量減少量が大きくなる.

図 22 は, 衝突角度 $60^{\circ} ， 45^{\circ}$ の実験加単位時間当たりの質量減少量と流速の垂直成分 $V \sin \theta$ の関係，及ひ衝突角 度 $90^{\circ}$ で流速を変化させた時の質量減少速度と流速の関係を示したものである. 衝突角度 $60^{\circ}$ において, 試験面下向 きの結果は, 衝突角度 $90^{\circ}$ における各流速での実験結果と質量减少速度がほぼ同じであり, 試験面上向きの結果は, 衝突角度 $90^{\circ}$ における各流速での実験結果より質量減少速度が小さくなることがわかる. 衝突角度 $45^{\circ}$ 試験面下向き では，衝突角度 $60^{\circ}$ における試験面上向きの結果よりもさらに質量減少速度が小さくなる傾向を示している. 衝突角 度が小さくなるほど質量減少速度は小さくなり，質量減少速度は図 22 における斜線部の領域内におさまる. したがっ て, 液滴が成長しない環境下では, 衝突角度依存性は最も安全側の值として $V=V_{0} \sin \theta\left(V_{0}:\right.$ 流速, $\theta$ : 衝突角度 $)$ で 評価できることがわかる.

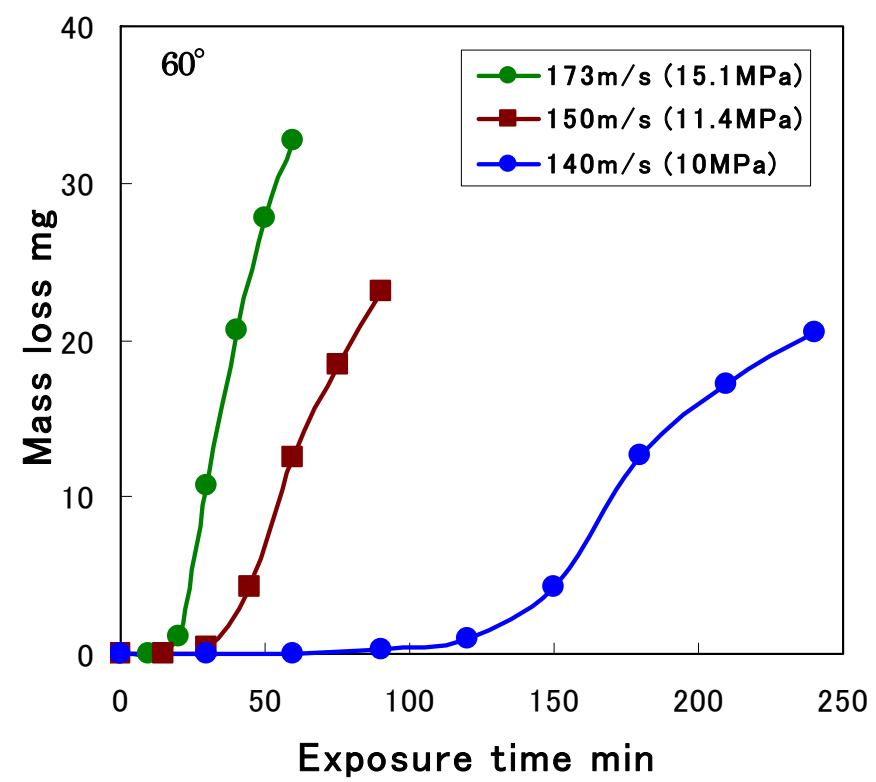

Fig.21 Mass loss-time curves of Al (Spray nozzle, 60 ${ }^{\circ}$ )

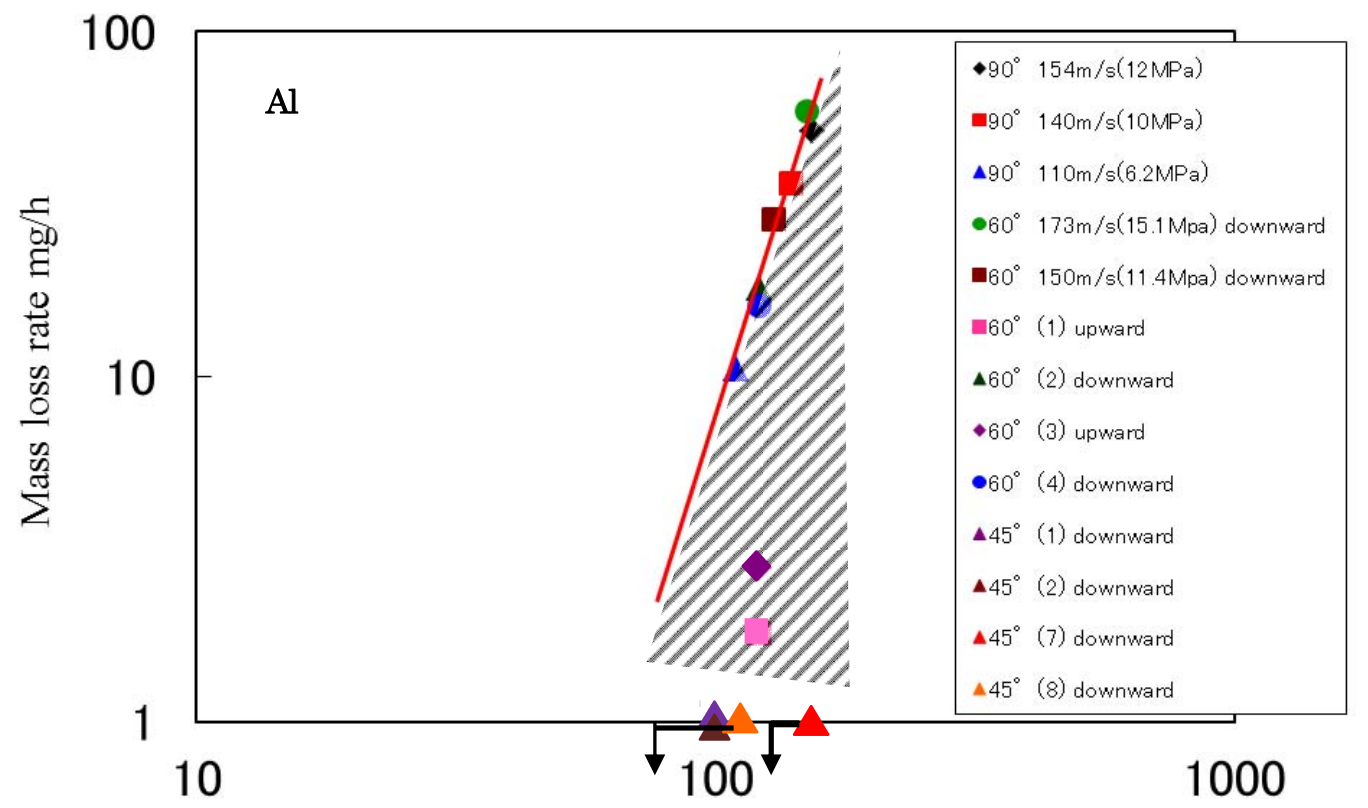

Flow velocity $V \sin \theta \mathrm{m} / \mathrm{s}$

Fig.22 Relation between flow velocity $V_{0} \sin \theta$ and mass loss rate 


\section{4. 結 言}

（1）ジェットノズルを用いた液滴衝撃エロージョンのエロージョン深さ速度（MaxDER） は, 衝突角度によって大きく 変化し, 衝突角度が小さくなるにつれて減少する. いずれの材料も, MaxDER は $\sin ^{\mathrm{n}} \theta$ で整理され, n は S15C, SUS304，STPA24 に対してそれぞれ 1.7，1.2，2.5 となり，ほぼ同程度の值をとる.

(2) 高圧法のジェットノズルを用いた試験では，衝突角度が小さくなると，試験片表面の液膜は吹き飛ばされ，水膜 の保護作用がほとんどない状態でエロージョンが起こるため，エロージョン速度が衝突角度 $90^{\circ}$ の低流速の結果 に比べて大きくなる，逆に，衝突角度 $90^{\circ}$ では，試験片表面に厚い液膜が生じ，水膜の保護作用の下でエロージ ヨンが進むと考えられる.

(3) スプレーノズルによるエロージョンは, 衝突角度依存性は最も安全側の值として $V=V_{0} \sin \theta \quad V_{0}:$ 流速， $\theta$ : 衝突 角度）で評価できる.

\section{謝 辞}

この研究の一部は，経済産業省原子力安全・保安院の高経年化対策強化基盤整備事業の一環として実施した. また，本研究 で使用した扇形ノズルからの液滴径のザウター平均值は，新潟大学工学部 藤沢 延行 教授にご教示いただいた. ここに記し て謝意を表す。

\section{文献}

（1）日本機械学会編，発電用設備規格 配管減肉に関する規格，JSMECA1－2005 (2005)，日本機械学会，p. 47.

(2) Heymann, F. J., "Conclusions from the ASTM Interlaboratory Test Program with Liquid Impact Erosion Facilities", Proc. 5th Int. Conf. on Erosion by Liquid and Solid Impact (1979), pp. 20.1-20.10.

(3) 服部修次，中村隆太，林崗，“液滴衝撃エロージョンに及ぼ寸液滴径の影響”，日本機械学会論文集 A 編，Vol. 77, No. 782 (2011), pp. 202-211.

(4) Fyall, A. A., King, R. B. and Strain, R. N. C., "Rain erosion aspects of aircraft and guided missiles", Journal of Royal Aeronautic Society, Vol. 66 (1962), pp. 447-453.

(5) Busch, H., Hoff, G. and Langbein, G., "Rain Erosion Properties of Materials", Philosophical Transactions. A, Vol. 260, No. 1110 (1966), pp. 168-178.

(6) Hoff, G., langbein, G. and Rieger, H., "Material Destruction Due to Liquid Impact", American Society for Testing and Materials, STP 408 (1967), pp. 42-69.

(7) Baker, C. W. C., Jolliffe, K. H. and Pearson, D., "The Resistance of Materials to Impact Erosion Damage", A Discussion on Deformation of Solids by the Impact of Liquids, Philosophical Transactions, Royal Society, Series A, Vol. 260, No. 1110 (1966), pp. 193-203.

(8) Hammitt, G., Kling, Y. C., Mitchell, T. M. Jr., and Solomon, L. P., "A Statistically Verified Model for Correlating Volume Loss Due to Cavitation or Liquid Impingement”, American Society for Testing and Materials, STP 474(1970), pp. 288-311.

(9) Schmitt, G F. Jr., "Erosion Rate-Velocity Dependence for Materials at Supersonic Speeds", American Society for Testing and Materials, STP 474 (1970), pp. 323-349.

(10) Schmitt, G. F. Jr., Reinecke, W. G. and Waldman, G. D., "Influence of Velocity, Impingement Angle, Heating, and Aerodynamic Shock Layers on Erosion of Materials at Velocities of $5500 \mathrm{ft} / \mathrm{s}(1700 \mathrm{~m} / \mathrm{s})$ )", American Society for Testing and Materials, STP 567 (1974), pp. 219-238.

(11) Gorham, D. A. Matthewson, M. J. and Field, J. E., "Damage Mechanisms in Polymers and Composites Under High-Velocity Liquid Impact", American Society for Testing and Materials, STP 664 (1979), pp. 320-339.

(12) Ahmad, M., Casey, M., Surken, N., "Experimental assessment of droplet impact erosion resistance of steam turbine blade materials", Wear, Vol. 267 (2009), pp. 1605-1618.

(13) ASTM ed., Annual Book of ASTM standards 2005, Wear and Erosion; Metal corrosion, G134-95(2005), pp. 576-588, ASTM International.

(14) 服部修次, 早川裕規, “炭素鋼, ステンレス鋼の液体衝撃エロージョンの流速依存性”, 日本機械学会論文集 A 編, Vol. 76, No. 772 (2010), pp. 179 - 186. 